\title{
Diversity of Vascular and Insects Canopy Epiphytes on Palm Oil in North Sumatra, Indonesia
}

\author{
Fitra Suzanti ${ }^{1}$, Retna Astuti Kuswardani ${ }^{2}$, Suci Rahayu ${ }^{3}$, Agus Susanto ${ }^{4}$ \\ ${ }^{1}$ Biology Education Study Program, University of Riau, Riau, Indonesia \\ ${ }^{2}$ Faculty of Agriculture, University of Medan Area, Medan, Indonesia \\ ${ }^{3}$ Faculty of Mathematics and Natural Sciences, University of North Sumatra, Medan, Indonesia \\ ${ }^{4}$ Palm Research Center of Marihat, North Sumatra, Indonesia
}

Email address:

fitrausu@gmail.com (F. Susanti)

\section{To cite this article:}

Fitra Suzanti, Retna Astuti Kuswardani, Suci Rahayu, Agus Susanto. Diversity of Vascular and Insects Canopy Epiphytes on Palm Oil in North Sumatra, Indonesia. American Journal of Environmental Protection. Vol. 5, No. 3, 2016, pp. 39-49. doi: 10.11648/j.ajep.20160503.11

Received: March 22, 2016; Accepted: March 31, 2016; Published: April 20, 2016

\begin{abstract}
This paper describes the role of the insect, which is essential for human survival, but still people are not familiar with widely even some people consider insects no meaning or viewed from the downside. Diversity of epiphytes and insects in the canopy of palm oil plantations in North Sumatra assessed by field observations at five locations, namely, Bukit Sentang, Padang Mandarsyah, Ajamu, Sijambu-jambu, and Aek Pancur. Data were analyzed using qualitative and quantitative. Based on the results obtained by analysis of the biological diversity of insects that affect the quality and quantity of farm products. In natural ecosystems, generally there has been a stable population of pests and their natural enemies so that the presence of insect pests in cropping is no longer harmful. Thereby, the conditions need to be developed so as to reduce the use of pesticides to control pests in field crops, especially in export-oriented and has high economic value.
\end{abstract}

Keywords: Diversity, Vascular Epiphytes, Insects Canopy, Oil Palm Plantations

\section{Introduction}

Instability of the agro-ecosystem and increasing of pest infestation is caused by changing in natural ecosystems, making the main crop plantation ecosystem type (monoculture), so the diversity of micro-habitats to be reduced. Agriculture sustainable can be realized by reducing the action of pests through the use of natural enemies of insects and increasing the diversity of plants. This needs to be done to improve the stability of the ecosystem and reduce the risk of pests [1]. One of the diversity of plants in the ecosystem of oil palm plantations is a vascular epiphytes. These weeds are grouped in the plantation, because their numbers are small $(1.5 \%)$ compared with other weeds so often overlooked existence [2]. The type is ferns, ficus and other wood. It provides an important resource and habitat for many animals and microorganisms including eating insects, and vertebrates nectarivorous fruit-eating bats and birds in particular. [3] found the presence of epiphytes in a coffee plantation turned out to support more insects compared with no epiphytes. The presence of epiphytic provide a valuable resource for arthropods.

As long as this is done in oil palm plantations is controlling epiphyte epiphytic ferns woody and let live, as long as their presence does not interfere with harvesting and plant maintenance. Information about epiphytes in oil palm plantations, both in terms of ecology, insects contribution to the canopy and also the microclimate created is still small. It is necessary for better understanding of the ecology on human modified ecosystems to support the conservation of the landscape level [4]. Natural ecosystem with a simpler artificial ecosystem is more easily shaken by pests caused fewer species $[5,6]$. Biodiversity in monoculture plantations are low, may result in lower complexity compared to other natural habitats. It seemed from the tree whose age is uniform, lower canopy, and almost no bush. This is a result of human disorders that are high in oil palm plantations [7, 8]. It is part of the ecosystem, and has a function in the cycle of nutrients and water, which changes the composition of epiphytes can have negative effects, affecting the ecosystem 
processes in general $[9,10]$.

The survival and distribution of epiphytes is dependent on the density of porofit, microclimate, the distance from the seed source, the type and size of the tree, the type and history of the disorder, epiphytic population dynamics of trees and epiphytes physiology [11]. Bryophyta and epiphytes richness of coverage decreased from the tree to the top of the stem, while increasing the wealth of moss and lack of coverage of the base to the top of the rod [12]. There are 136 species of weeds, which consists of 33 families dikotil, 3 families of monocots and 8 families Pterydophyta of weeds [13].

Weed of the family Poaceae and Asteraceae is very invasive. Chromolaena odorata, Aspillia africana and Melanthera scandens of Asteraceae, maximum Panicum and Imperata cylindrica of Poaceae and Euphorbiaceae Mallotus oppositifolius of widespread and problematic. [14] stating there is a correlation of epiphytic vegetation on the palm Socratea Exorrhiza with increased diameter, the age of the tree and Bryophyta cover. The most common epiphytes are three species of fern, which Ananthacorus angustifolius, Elaphoglossum sporadolepis and Dicranoglossum panamense. [1] found that weeds affect diversity and the existence of herbivorous insects and their natural enemies in the farm system. Flowers certain weeds (mostly Umbelliferae, Leguminosae and Compositae) plays an important role as a source of adult parasitoids feed which can suppress the insect pest population. Natural mechanisms such as predatisme, parasitism, pathogenicity, and interspesies intraspesies competition, succession, productivity, stability and biological diversity can be utilized to achieve sustainable agriculture.

The expansion of monoculture crops at the expense of natural vegetation is the result in reduced diversity of local habitats, eventually leading agro-ecosystem instability and increased pest attacks. Commodity crops modified to meet human needs will be damaged due to high pest infestation. Generally, the more intensive the plant is modified it will be more intensive pest attack him anyway. Characteristic properties of its own settings commodity will naturally disappear when humans modify these commodities by breaking the interaction of plant life and eventually becomes brittle. This solution can be improved with the recovery of commodity components through the addition or enhancement of biodiversity. [15] stated polyculture in annual plants is more supportive of herbivores to a level lower than monocultures, in terms of the dynamics of insects. This trend is caused by the stability of the natural enemy population with the availability of food sources and habitat micro continuously. Another possibility is certain herbivores prefer similar habitats on the plant, which provides centralized all its needs, and the physical conditions are always the same. Manipulation using cover crops (cover crops) also affect insect pests and their natural enemies. Orchard with wild plants underneath a lower damage by insect attacks than cultivated orchards free of other plants (clean cultivated), because of the abundant amount and efficiency of predators and parasitoids.
Plants are the main source of feed for herbivorous insects, because it provides a compound of the main nutrients, namely carbohydrates, proteins, amino acids, vitamins, minerals, and water. Nitrogen $(\mathrm{N})$ in the form of protein and amino acids in the plant tissue is one of the reasons herbivorous insects choosing one type of plant as their food source [16]. The main role of nitrogen in the metabolic processes that improve the health, growth, proliferation, and resistance organism to make this element as a factor limiting in nature. Insects are generally grouped into insect pests, useful insects and insect neutral from the standpoint of farming. As useful organisms, insects on the role of natural enemies either as parasitoids and predators, insect pollinators and decomposers. While neuters often fall prey to predators, so a very large role in maintaining the balance of the ecosystem. Insect biodiversity affects the quality and quantity of product produced. In natural ecosystems, generally there has been a stable population of pests and their natural enemies so that the presence of insect pests in cropping is no longer harmful. These conditions need to be developed so as to reduce the use of pesticides to control pests in field crops, especially in export-oriented and has high economic value. Insects have a role that is essential for human survival, but the role of these insects is still less known by the public and even some people consider insects no meaning or viewed from the downside. This became the basis of a multifaceted assessment canopy epiphytes and insects in oil palm plantations in North Sumatra.

\section{Method}

The study was conducted at five locations in North Sumatra oil palm plantations, namely on the Bukit Sentang, Padang Mandarsah, Ajamu, Sijambu-jambu and Aek Pancur. Identification of epiphytes and insects do in Herbarium Medanense, Biology laboratory of North Sumatra University, PPKS Marihat, Laboratory and LIPI Cibinong.

\subsection{Equipment and Materials}

The tools used in the study are shears, knife, hatchet, yarn, pencils, books field (collector book), etiquette hanging, binoculars, plastic bags, stairs, Egrek, mistblowwer Maruyama MD 1800X, Knapsact spayer Solo 425, bottle collection, magnifying glass, tool documentation, digital termohygrometer TFA, bouffant/ herbarium presses, newsprint, fabric insect container, cardboard insulation, rubber/ rope/ wire bond, a razor and a location map. The materials used are $70 \%$ alcohol, the herbicide paraquat dichloride and $276 \mathrm{~g} / \mathrm{l}$, insecticide Deltamethrin $25 \mathrm{~g} / 1$.

\subsection{Research Procedure}

The location is determined through field observation, and secondary data collected to get a diversity of epiphytes and insects. Identification carried out on the park boundaries, limits each location, topography of the region, the oil age, location maps, soil conditions, climate and average annual 
secondary data. Palm oil grouped into three age groups, namely the age of 1-5 years, 6-15 years and over 15 years at each study site and calculated diversity epifitnya. The observation is made with a size of $20 \mathrm{~m} \times 20 \mathrm{~m}$, with each age group as many as five plots. The laying of the plot is done by purposive sampling, with Objective for the entire community of the various existing topography can be represented. The number of trees was observed in one observation plot is 3 trees. Observations epiphytes that grow on the trunk and canopy carried by climbing poles or using outreach and assistance binoculars.

The type and amount of epiphytes attached to the palm tree stands were observed as well as sorting plant species of vascular epiphytes. For the kind already known are immediately noticed, and that is not known to be made of specimens sampled herbariumnya. Herbarium made wet and dry. Herbarium specimens are used to wet watery, mushy and hard dried, such as fruits and orchids pseudobulb. Dried herbarium specimens are used to form sheets or rods can be dried.

Identification of epiphytic plants is done by reference to the Taxonomy of Vascular Plants [17], Type of Paku Indonesia [18], Fern of Malaysia In Colour [19], Comparative Morphology of Plants Vasculat [20]. The data were analyzed qualitatively and quantitatively. Quantitative analysis was carried out on the kinds of epiphytic plants to determine the density and frequency of species at each location. Epiphyte communities steadiness level at each location is calculated using diversity index and Evenness Index Shannon-Wiener type [21] and a kind of similarity between locations tested with Sorensen similarity index [22].

Observations and insect diversity calculation is done in the age group of trees. Spraying insect was conducted in the morning around $09.00 \mathrm{pm}$ and evenings $7 \mathrm{pm}$. Spraying insecticide active ingredient Deltamethrin (synthetic pyrethroid compounds) with the recommended dose is was done on each of 10 trees per age group. Each of these insect tree container fitted cloth measuring $1 \mathrm{x} 1 \mathrm{~m}$ by the two individual trees. After 30 minutes fabric pitcher taken, and insects that falls is collected and put into a bottle containing $70 \%$ alcohol to be identified.

Differences in the structure of insects among the research sites is done by calculating the diversity index of each location and compare them. Diversity index calculated by the formula Shannon-Wiener. Then calculated the index evenness (E), the similarity of Sorensen index (ISS). Further views the relationship between the diversity of epiphytes and diversity of insects with a simple correlation, and the relationship between the diversity of epiphytes and diversity of insects with climate [23].

\section{Results and Discussion}

At five locations are obtained 87 species of vascular epiphytes with the overall number of 65751 people, included into 37 tribes. Epiphytes are grouped into three classes, namely class Filicopsida with 11 tribes, Liliopsida class with five tribes, and Class Magnoliopsida with 20 tribes as in Table 1. Based on the nature of his group can not be considered a true epiphytes, but rather tends included hemiepifit.

Table 1. Composition of vascular epiphytes in North Sumatra oil palm plantations.

\begin{tabular}{lllllll}
\hline $\begin{array}{l}\text { The } \\
\text { composition } \\
\text { of epiphytes }\end{array}$ & I & II & III & IV & V & \\
\cline { 2 - 7 } & Location & & & \\
\hline $\begin{array}{l}\text { Number of } \\
\text { Individuals }\end{array}$ & 13.380 & 11.013 & 7.989 & 11.625 & 21.744 & 65.751 \\
$\begin{array}{l}\text { Number of } \\
\text { Species }\end{array}$ & 21 & 37 & 23 & 62 & 34 & 177 \\
$\begin{array}{l}\text { Number of } \\
\text { Genus }\end{array}$ & 18 & 31 & 21 & 47 & 29 & 146 \\
$\begin{array}{l}\text { Total of } \\
\text { Family }\end{array}$ & 16 & 19 & 16 & 30 & 23 & 104 \\
\hline
\end{tabular}

Description:

I = Bukit Sentang Gardens; II = Padang Mandarsyah Gardens; III = Ajamu Gardens; IV = Sijambu-jambu Gardens; V = Aek Pancur Gardens

Overall the number of species of epiphytes in the fifth location is more than the epiphytes in natural forests. This is in line with the findings [24], ie there are 47 kinds of macro epiphytes, and 26 kinds of macro epiphytes in Forest Tourism Tangkahan TNGL Langkat. However epiphytes are found largely not true epiphytes (holoepiphytes) as found in natural forests. In general, a shortage of plantation species are protected, but is dominated by species that are not protected $[25,26]$.

The number of epiphytic vascular found is relatively large, due to the presence of plant species that are not included epiphytic true but the chance to grow on palm trunks like Asystasia gangetica, Elaeis guineensis, Clidemia hirta and other types of Liliopsida nations and magnoliopsida also called epiphytic accidental, there is also hemiepifit and facultative epiphytes. It was found that hemiepifit more resistant than holoepifit to habitat change because they are rooted in the ground (most of his life) in line with the findings $[27,28]$. It's hard to find true epiphytes in oil palm plantations, almost all epiphytes are found in palm trees are also found living in the soil. Group of ferns (Pteridophyta) is most prevalent, namely family of davalliaceae, Nephrolepidaceae, Polypodiaceae, Vittariaceae, Adiantaceae, Pteridaceae, Dryopteridaceae, Atthyriaceae, Aspleniaceae, Thelypteridaceae, Hymenophyllaceae and Ophioglosaceae.

The longer a plantation allowed, then a chance for epiphytes to grow and grow bigger. This is a reflection of the nature of the ecosystem that always moves towards equilibrium (homeostasis). Vascular types found are shown in Table 2. 
Table 2. Vascular epiphytes in North Sumatra oil palm plantations.

\begin{tabular}{|c|c|c|c|c|c|c|c|}
\hline \multirow{2}{*}{ No } & \multirow{2}{*}{ Spesies } & \multicolumn{5}{|c|}{ Location } & \multirow{2}{*}{-Number } \\
\hline & & I & II & III & IV & $\mathbf{V}$ & \\
\hline 1 & $\begin{array}{l}\text { Nephrolepis } \\
\text { biserrata }\end{array}$ & 9486 & 2658 & 3567 & 3795 & 7176 & 26682 \\
\hline 2 & G. verrucosum & 1782 & 1389 & 1539 & 1731 & 4518 & 10959 \\
\hline 3 & $\begin{array}{l}\text { Vittaria } \\
\text { elongata }\end{array}$ & 324 & 537 & 1041 & 1143 & 6678 & 9723 \\
\hline 4 & $\begin{array}{l}\text { Asystasia } \\
\text { gangetica }\end{array}$ & 126 & 1668 & 84 & 819 & 633 & 3330 \\
\hline 5 & $\begin{array}{l}\text { Davallia } \\
\text { divaricata }\end{array}$ & 66 & 1689 & 330 & 117 & 621 & 2823 \\
\hline 6 & $\begin{array}{l}\text { Elaeis } \\
\text { guineensis }\end{array}$ & 552 & 591 & 297 & 783 & 531 & 2754 \\
\hline 7 & $\begin{array}{l}\text { Peperomia } \\
\text { pellucida }\end{array}$ & 357 & 642 & 36 & 681 & 318 & 2034 \\
\hline 8 & $\begin{array}{l}\text { Vittaria } \\
\text { ensiformis }\end{array}$ & 48 & 306 & 24 & 723 & 210 & 1311 \\
\hline 9 & G. integrifolium & 9 & 6 & 6 & 3 & 21 & 45 \\
\hline
\end{tabular}

Type Nephrolepis biserrata, Goniophlebium verrucosum, and Davallia divaricata similar to those found by the [29] in the oil palm plantations of Malaysia and Singapore. Vittaria elongata and Vittaria ensiformis is the type often found in old oil palm plantations. Asystasia gangetica is a terrestrial shrubs and plants, including invasive especially in disturbed habitats. Gymnopetalum integrifolium and Peperomia pellucida including hemiepifit, while Elaeis guineensis is a plantation crop. Vascular epiphytes are most commonly found is Nephrolepis biserrata and Goniophlebium verrucosum as shown in Figure 1a and 1b. If at first glance these two types seems to be almost the same as growing mixes in the palm tree. To distinguish to note the shape and position of the spores. Both types of epiphytes is found almost exclusively in tree eraser even sometimes cover the surface of the rod.

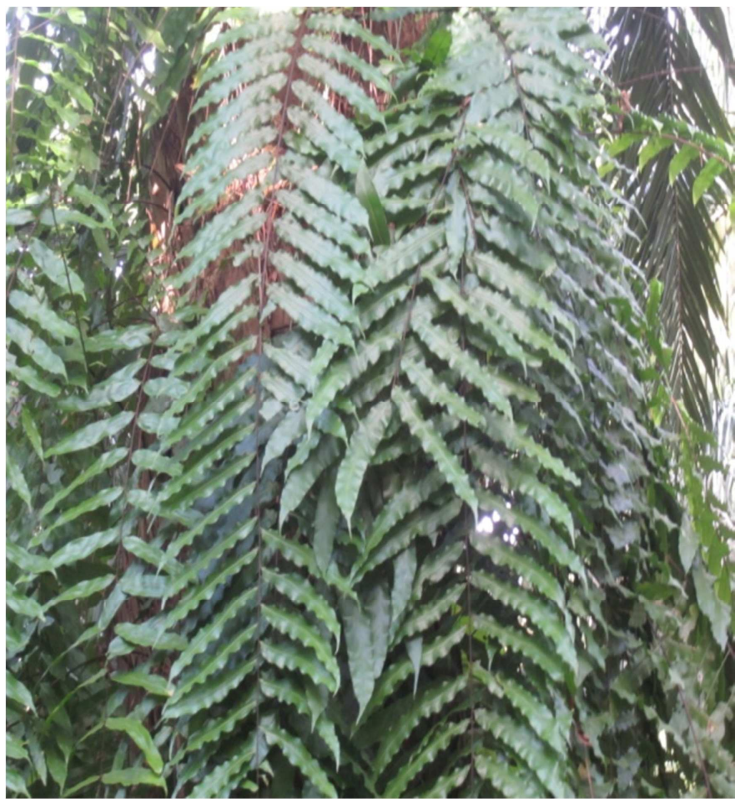

Figure 1a. Nephrolepis biserrata.

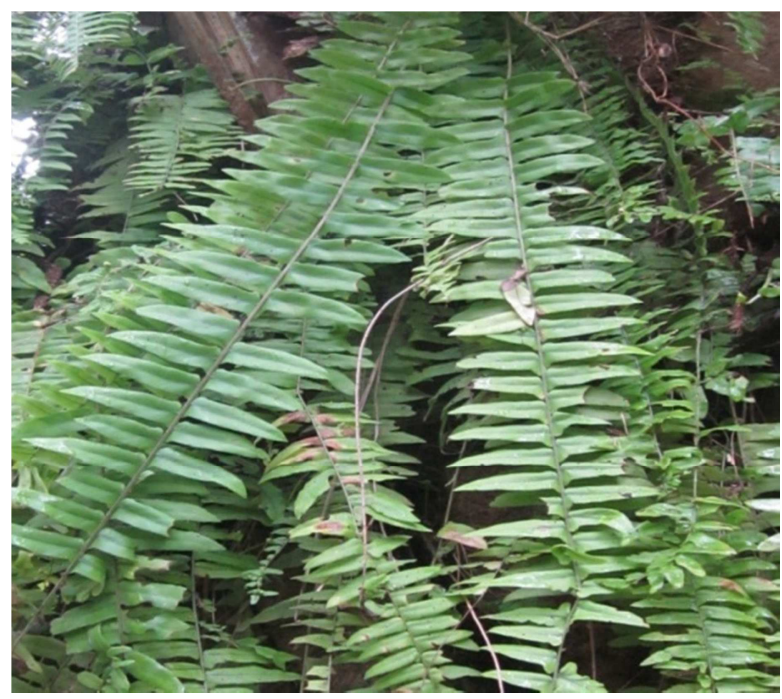

Figure 1b. Goniophlebium verrucosum.

Type Davallia divaricata (Figure 2a) are found in trees exposed to sunlight. On the inside of the garden that is less sunlight of this type are rare, if there is only a little. Elaeis guineensis (Figure $2 b$ ) excluding epiphytes because this plant is used to grow here because of their palm kernel spilled at harvest time and germinate in the palm trunks. At first, its presence does not interfere as well as other epiphytes, but if left will be parasite. The roots of this plant will try to look for land to meet the needs of the water so it would be a competitor for its host tree.

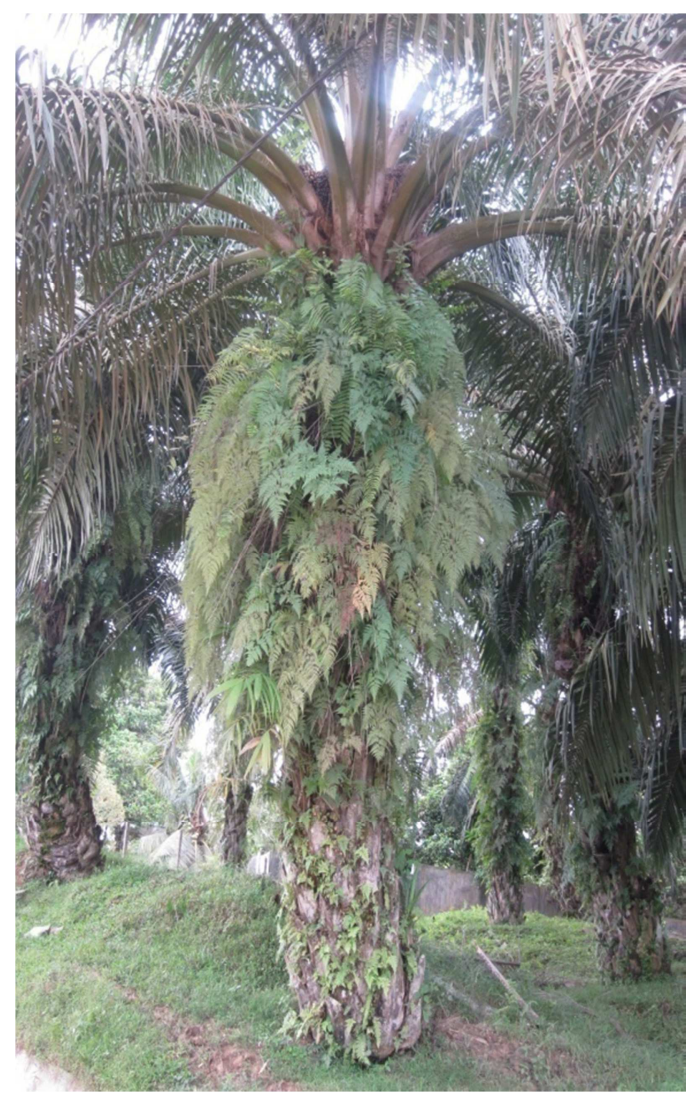

Figure 2a. Davalia divaricate. 


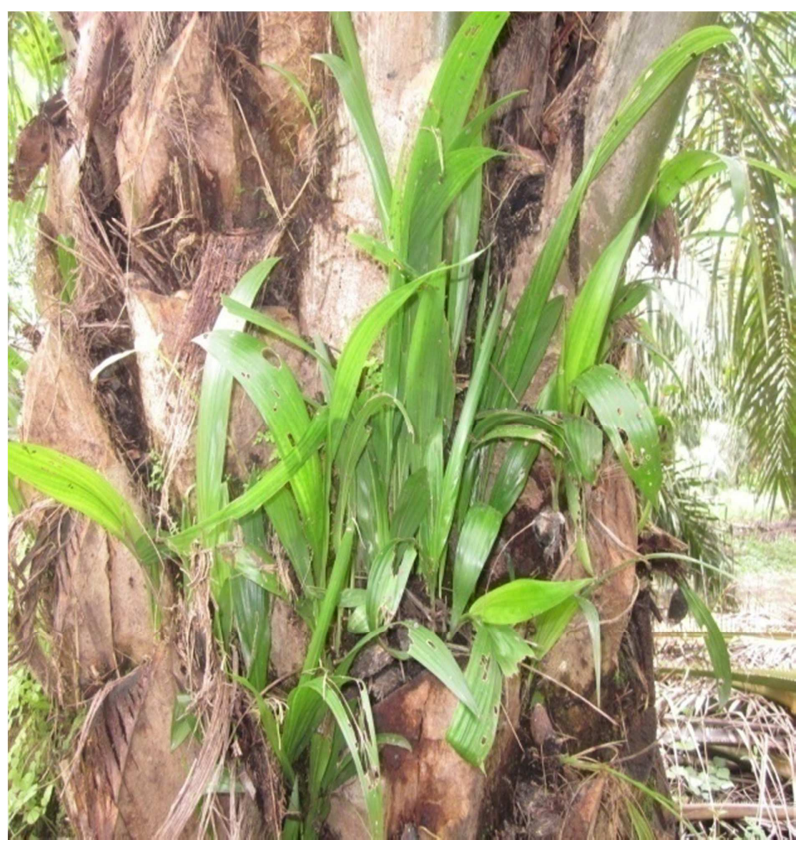

Figure 2b. Elaeis guineensis.

Epiphytes usually take advantage of the remaining pieces of leaf midrib as a place to grow, because this is where a lot of accumulated dust, litter and other nutrients needed by epiphytes to grow and develop. Thus the age difference palm will automatically affect the existence of epiphytes. The age difference will affect the stems and fronds as a place to grow epiphytes. Palm oil was aged 1-5 years have a short tree and its trunk is intact or not cut pelepahnya. Even if there is cut pelepahnya only a few are usually not more than 10 midrib. Oil palm frond aged 6-15 years who cut many with stem height of about 1-10 m while the palm over the age of 15 years is usually pelepahnya started off so the stems partly bald look. Number of species of epiphytes at five locations for the three age groups are the most common type found in the age group of 6-15 years unless Padang Mandarsyah Gardens location where the highest number of species that are in the age group 1-5 years and in the Bukit Sentang garden, the number of species in the group age 1-5 years is equal to 6-15 years.

Many types of vascular epiphytes in the age group 6-15 years due to oil palm fronds so epiphytes have been a lot of media to grow a lot. The remaining pieces of this frond will hold a lot of dust, debris and other nutrients and water so as to create a good habitat for the growth of several types of vascular epiphytes. This is in line with the findings [30], that the vertical stratification is one of the factors that affect the distribution of life niches (niche) on epiphytic plants. This vertical stratification generated by differences in height different oil palm planting year. Differences in plant height is related to the possibility of catching the seeds of epiphytes that can be spread by wind or insects further that not only affect plant height, age also has an effect in terms of providing the right layer in helping the growth of epiphytes. This situation is illustrated shown in Figure 3.

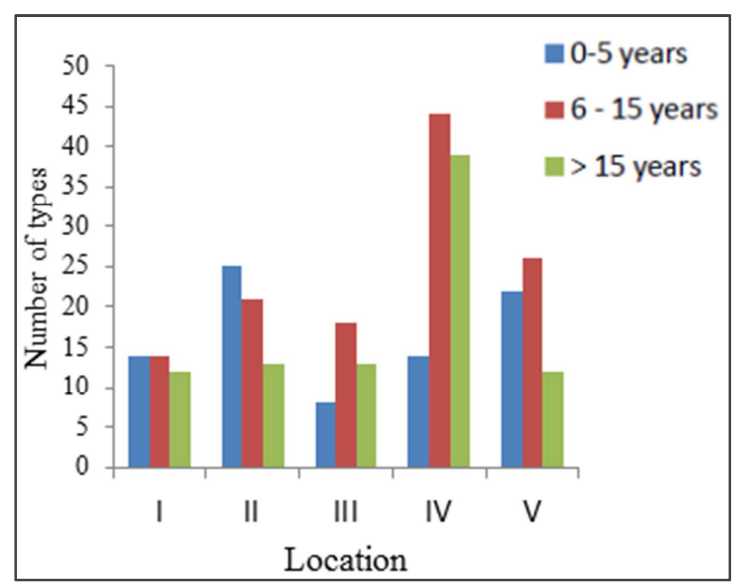

Figure 3. The number of vascular epiphytes in three age groups in five locations of oil palm plantations of North Sumatra.

Description: $\mathrm{I}=$ Bukit Sentang Gardens

II = Padang Mandarsyah Gardens

III = Ajamu Gardens

IV $=$ Sijambu-jambu Gardens

$\mathrm{V}=$ Aek Pancur Gardens

Relations epiphytes number of individuals in each age group indicate a trend, namely the older the age of the tree vascular epiphytes growing number of individuals who inhabit it. Except in Ajamu Gardens seen that in the age group above 15 years epifitnya less than the age group 6-15 years. Means the type of epiphytic win the competition with other species growing breed and number of individuals more so that this type become the dominant species. This is in line with the findings of [31], that the bigger or getting older a tree then the carrying capacity for the growth of epiphytes are also getting bigger and so are the findings [32] and [33] which explains that the larger the tree will be more extensive surfaces inhabited by epiphytes. Number of individuals of epiphytes at five locations shown in Figure 4.

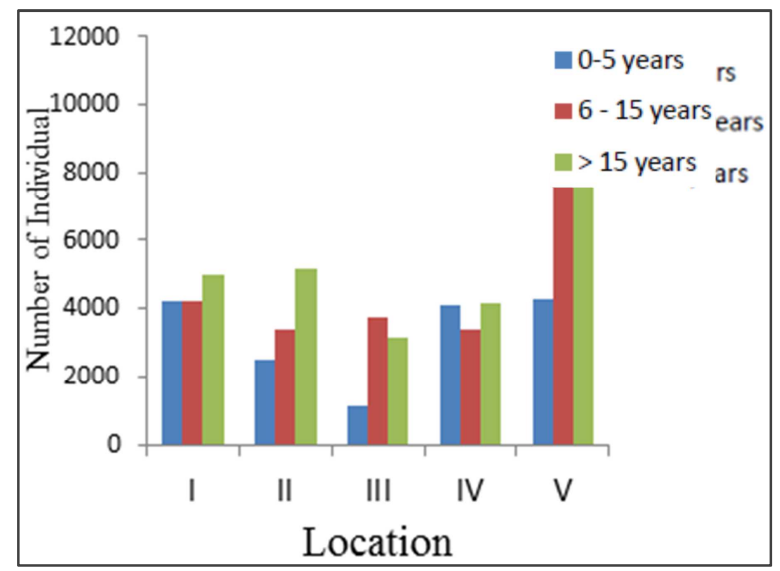

Figure 4. Number of Individuals of vascular epiphytes in three age groups in five locations.

Description: $\mathrm{I}=$ Bukit Sentang Gardens

II = Padang Mandarsyah Gardens

$\mathrm{III}=$ Ajamu Gardens

IV $=$ Sijambu-jambu Gardens

$\mathrm{V}=$ Aek Pancur Gardens 
The number of individuals of the epiphytic contained in oil palm over the age of 15 years Ajamu Gardens is lower than the age of 6-15 years, because the sample for the age group above 15 years of residual pelepahnya many are separated from the tree, so that the media place to grow epiphytes also the less. Oil palm is old, it's midrib start off one by one. Midrib detachment process was followed by the fall of epiphytic riding her life. This resulted in a reduced number of epiphytes contained in palm tree. Epiphytes overgrown palm only on the top of the stem, while the stem lower part relatively clean of epiphytes. This is in line with the findings [34] that the reduction porofit parts will result in decreased diversity of epiphytes.

The highest relative density which is kind of Nephrolepis biserrata at five locations. This shows that this type of match live on oil palm plantations, and are not influenced by geographical location, temperature, humidity and other environmental factors. Possible nutrients and a place to grow palm oil supplied to meet the needs of this plant. This type of relative control of most palm trunks and got rid of the other species that are less resistant. This is in line with the findings [35] that the spikes of the family Polypodiaceae including vascular epiphytes like habitat disturbed, so he can take advantage of anthropogenic disturbance, and it might be better if he lives in a managed environment of the human being in the natural environment. Diversity index illustrates the stability of vegetation as outlined in Table 3.

Table 3. Diversity Index $\left(H^{\prime}\right)$ of vascular epiphytes in five locations for the three age groups of palm oil in North Sumatra.

\begin{tabular}{llll}
\hline \multirow{2}{*}{ Location } & \multicolumn{2}{l}{ Age } \\
\cline { 2 - 4 } & $\mathbf{1 - 5}$ Years & $\mathbf{6 - 1 5}$ Years & > 15 Years \\
\hline Bukit Sentang & 1.06 & 1.16 & 0.97 \\
Padang Mandarsyah & 2.11 & 2.00 & 1.92 \\
Ajamu & 0.72 & 1.78 & 1.7 \\
Sijambu-jambu & 1.55 & 2.19 & 2.45 \\
Aek Pancur & 1.5 & 1.46 & 0.95 \\
\hline
\end{tabular}

Diversity of vascular epiphytes were highest in the age group above 15 years old in the Sijambu-jambu garden is by 2,45 index. Because of at this location, the community are quite old and not too many human disorders. Based on the information and conditions in the field this location it's is epifitnya never discarded unless the condition is very disturbing harvest. While in other locations epifitnya more often disposed hygiene purposes and policies maisng garden of the gardens. Based on this, the more often a disturbance, the lower the diversity epifitnya. This is in line with the opinion of the [28] which states that if there is a reduction of midrib means a place to grow epiphytes is also reduced so that the diversity epifitnya was reduced. Action to reduce the parts porofit created the conditions for dry and sunny can result in decreased diversity of epiphytes. Distribution of individuals of each species of epiphytic described by evenness index (E) as shown in Table 4.
Table 4. Evenness Index (E) of the vascular epiphytes in three age groups of palm oil in North Sumatra.

\begin{tabular}{llll}
\hline & Years & 6-15 Years & >15 years \\
\hline Bukit Sentang & 0.4 & 0.42 & 0.39 \\
Padang Mandarsyah & 0.66 & 0.66 & 0.75 \\
Ajamu & 0.35 & 0.62 & 0.66 \\
Sijambu-jambu & 0.59 & 0.58 & 0.67 \\
Aek Pancur & 0.50 & 0.44 & 0.38 \\
\hline
\end{tabular}

The above data shows that the highest evenness when all of the same species have the same number of individuals or equally abundant. The similarity of organisms that can live in two different places is showing its spread, and can also be used to determine its spread. And the similarities between the existing types of epiphytes are shown in Table 5.

Table 5. Similarity Index (ISS) of vascular epiphytes on five oil palm plantations in North Sumatra (\%).

\begin{tabular}{llllll}
\hline Location & I & II & III & IV & V \\
\hline I & 100 & 41 & 50 & 42 & 51 \\
II & 41 & 100 & 52 & 46 & 42 \\
III & 50 & 52 & 100 & 38 & 49 \\
IV & 42 & 46 & 38 & 100 & 40 \\
V & 51 & 42 & 49 & 40 & 100 \\
\hline
\end{tabular}

Description:

$\mathrm{I}=$ Bukit Sentang; II = Padang Mandarsyah; III = Ajamu; IV = Sijambujambu; $\mathrm{V}=$ Aek Pancur

Index of similarity of the five research sites ranging from $38 \%$ to $52 \%$, where the location of which has an index of similarity is the smallest comparison site III (Ajamu) conveniently IV (Sijambu-guava) and the highest is a comparison site II (Padang Mandarsyah) with location III (Ajamu). This is in line with the findings of [36] that the greater the similarity index then it means the same type at different locations each. The composition of the canopy insects include only the insect class by the number of 10264 individuals were included in the Order 17, 147 families as shown in Table 6.

Table 6. The composition of canopy insects in North Sumatra oil palm plantations.

\begin{tabular}{llllll}
\hline \multirow{2}{*}{$\begin{array}{l}\text { The composition of } \\
\text { Insects }\end{array}$} & \multicolumn{2}{l}{ Location } & & & \\
\cline { 2 - 6 } & I & II & III & IV & V \\
\hline Number of Individuals & 1056 & 1332 & 1539 & 2222 & 4115 \\
Number of Family & 74 & 67 & 75 & 102 & 78 \\
Number of Order & 10 & 10 & 9 & 11 & 11 \\
\hline
\end{tabular}

Description:

$\mathrm{I}=$ Bukit Sentang garden; II = Padang Mandarsyah garden; III = Ajamu garden; IV = Sijambu-jambu garden; $V=$ Aek Pancur garden

Based on data from the composition and structure of vascular epiphytes, it appears that Sijambu-jambu gardens has a number of species, family and genus of epiphytic most, 
demikianjuga by the number of families of insects most. This shows that the presence of epiphytic provide homes and food for many insects canopy. In line with the findings of [37], the more diverse epiphytes that grow on the tree canopy also increasingly diverse micro-habitats which can be occupied by insects so the variety of all insects that live in the tree canopy. Epiphytes also increases diversity by creating an environment arthropod soil and litter as habitat and foliage consumed by herbivorous insects. Based on the data of the composition of canopy insects in three age groups and five locations, obtained diversity index, which is one indicator of the stability of an ecosystem. The higher the diversity index showed more complicated or complex the food web, which means also more stable or better an environment. Index canopy insect diversity in North Sumatra oil palm plantations are shown in Table 7.

Table 7. Diversity Index $\left(H^{\prime}\right)$ insect canopy in three age groups of palm oil in North Sumatra.

\begin{tabular}{llll}
\hline \multirow{2}{*}{ Location } & \multicolumn{2}{l}{ Age } & \\
\cline { 2 - 4 } & $\mathbf{1 - 5}$ Years & Years & >15 Years \\
\hline Bukit Sentang & 1,81 & 2,39 & 2,29 \\
Padang Mandarsah & 2,61 & 2,05 & 2,20 \\
Ajamu & 1,68 & 2,43 & 2,78 \\
Sijambu-jambu & 2,33 & 1,64 & 1,97 \\
Aek Pancur & 1,39 & 0,42 & 1,92 \\
\hline
\end{tabular}

Insect diversity of the five locations that are classified as being in all age groups, except in the garden Aek Pancur 6-15 years age group is low. This shows that the ecosystem is in a state of almost balanced. While in Aek Pancur age group 615 yrs unbalanced state of the ecosystem, because at this location has often done pest control with pesticides. When $\mathrm{H}$ $'<1$, it means low diversity, where the presence of insect pests and natural enemies are not balanced to make the damage to the plant, when $\mathrm{H}^{\prime}$ 1-3 means diversity medium, which leads to the well where the presence of pests and natural enemies in the field almost balanced, and if $\mathrm{H}^{\prime}>3$ means higher insect diversity, where the state of the ecosystem in the field is balanced, ie between pests and their natural enemies in balance so it does not need to be treated to kill insect pests [38]. There is no one location that high insect diversity index. Whilst in the natural forest insect diversity index is usually high [39]. It is associated with a lower diversity of vascular epiphytes in oil palm plantations. Overall it appears that the vegetation structure and floristic diversity complex will support a high diversity of insects. This is confirmed by [40] and [41], that the high degree of variation or diversity of plants affects the diversity of insects and insect populations.

[42] also stated that the plant diversity $75 \%$ less in oil palm plantations than natural forests. This resulted in a wealth of species in primary forest sites are on average five times higher than the plantation site [43]. In natural ecosystems all living things are in balance and control each other so there is no threat. In natural ecosystems, species diversity is very high, which means there is a space in any unity of diverse flora and fauna. The level of crop diversity affect the incidence of the pest problem. Diverse cropping systems affect the populations of pest species [44].

Distribution of canopy insects can be explained by the evenness index (E), which ranges from $0: 12$ to 0.67 . The lowest scores were found in the age group of 6-15 years in the Aek Pancur garden and the highest in the age group $>15$ years in the garden Ajamu. In the Bukit Sentang garden and Ajamu garden seen that the mature age of the plantation the higher the index Evenness. But in the garden Padang Mandarsah and Sijambu-guava, Evenness index is highest in the age group 1-5 yrs and 6-15 yrs lowest age group, as shown in Table 8 .

Table 8. Evenness index (E) of insects canopy in three age groups of palm oil in North Sumatra.

\begin{tabular}{llll}
\hline & $\mathbf{1 - 5}$ Years & $\mathbf{6 - 1 5}$ years & $>$ 15 Years \\
\hline Bukit Sentang & 0.51 & 0.61 & 0.63 \\
Padang Mandarsyah & 0.64 & 0.40 & 0.56 \\
Ajamu & 0.45 & 0.64 & 0.67 \\
Sijambu-jambu & 0.63 & 0.48 & 0.58 \\
Aek Pancur & 0.36 & 0.12 & 0.47 \\
\hline
\end{tabular}

Similarities canopy insects is determined by the similarity index, which is the study ranged from $56 \%-94 \%$ or including similar criteria [45]. The sites have the same major crops and species composition of epiphytic dominant also relatively similar, so micro-habitat conditions provided also almost the same as shown in Table 9. It is a major cause of canopy insects found also almost the same (similar).

Table 9. Similarity Index (IS) insect canopy on five oil palm plantations in North Sumatra (\%).

\begin{tabular}{llllll}
\hline Location & I & II & III & IV & V \\
\hline I & 100 & 70 & 67 & 56 & 64 \\
II & 70 & 100 & 76 & 94 & 68 \\
III & 67 & 76 & 100 & 64 & 69 \\
IV & 56 & 94 & 64 & 100 & 61 \\
V & 64 & 68 & 69 & 61 & 100 \\
\hline
\end{tabular}

Description:

I = Bukit Sentang; II = Padang Mandarsyah;III = Ajamu; IV = Sijambujambu; $\mathrm{V}=$ Aek Pancur

The relationship between the diversity of epiphytes and canopy insect diversity in North Sumatra oil palm plantations is shown in the model equation, $\mathrm{Y}=0.176 \mathrm{x}+1717$, with a value of $\mathrm{R} 2=0.024$. This shows that the diversity of insects can only be explained as much as $2 \%$ and as much as $98 \%$ more there are other factors that are not revealed. In Figure 5 also shows that the diversity of epiphytes and insect diversity are positively correlated, meaning the higher the diversity of its epiphytic insect diversity also increased. 


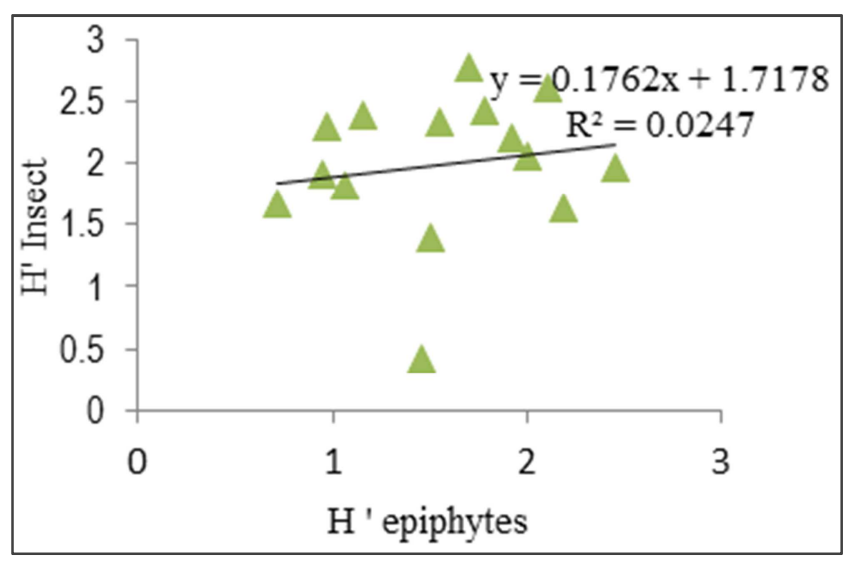

Figure 5. The relationship between the diversity of epiphytes with insect diversity in North Sumatra Oil Palm Plantation.

This relationship indicates that epiphytic vegetation provide important resources and habitat for many animals and microorganisms. Epiphytes that grow on palm trees will be a source of food, shelter and shelter canopy insects and other small animals. The more epiphytes that grow on the palm tree will be more and more varied food and a place that can be occupied by insects. The high diversity of epiphytes will increase the number of niche and micro habitat for insects. This resulted in a positive correlation between epiphytes and insects. However, many other factors that come into play has not been revealed in this study. In an ecosystem is always a mutual relationship between the constituent components of these ecosystems. Likewise in oil palm plantations, where epiphytes and insects will affect the ecosystems they occupy, reverse vascular epiphytes was also influenced by the physical state of the host environment. Epiphytic plants are very sensitive to changes in the composition of plants and micro-climate in an ecosystem so that the vascular epiphytes are often used as an indicator of disruption and change in an ecosystem [46] and [47].

The abundance of vascular epiphytes contribution Against Insects Canopies In Oil Palm in North Sumatra obtained by the ANOVA results shown in Table 10.

Table 10. The effect of age differences epiphytes and oil palm on the number of individual insects canopy (tail) in North Sumatra.

\begin{tabular}{|c|c|c|c|c|c|c|c|c|}
\hline \multirow{2}{*}{$\begin{array}{l}\text { Age Main plot } \\
\text { (A) }\end{array}$} & \multirow{2}{*}{$\begin{array}{l}\text { Subplot of } \\
\text { Epiphytes (B) }\end{array}$} & \multicolumn{5}{|c|}{ Number of insects (tail) } & \multirow[t]{2}{*}{ Total } & \multirow[t]{2}{*}{ Average } \\
\hline & & I & II & III & IV & $\mathrm{V}$ & & \\
\hline $\mathrm{A} 1$ & $\mathrm{~B} 1(100 \%)$ & 30 & 84 & 15 & 161 & 74 & 364 & 72,8 \\
\hline \multirow[t]{2}{*}{ (1-5 Years) } & $\mathrm{B} 2(50 \%)$ & 11 & 53 & 10 & 106 & 21 & 201 & 40,2 \\
\hline & $\mathrm{B} 3(0 \%)$ & 21 & 47 & 8 & 42 & 29 & 147 & 29,4 \\
\hline Total of A1 & & 62 & 184 & 33 & 309 & 124 & 712 & \\
\hline $\mathrm{A} 2$ & $\mathrm{~B} 1(100 \%)$ & 44 & 75 & 121 & 163 & 49 & 452 & 90,4 \\
\hline \multirow[t]{2}{*}{ (6-15 Years) } & $\mathrm{B} 2(50 \%)$ & 23 & 60 & 37 & 23 & 21 & 164 & 32,8 \\
\hline & $\mathrm{B} 3(0 \%)$ & 18 & 71 & 11 & 30 & 25 & 155 & 31 \\
\hline Total of A2 & & 85 & 206 & 169 & 216 & 95 & 771 & \\
\hline $\mathrm{A} 3$ & $\mathrm{~B} 1(100 \%)$ & 88 & 111 & 36 & 94 & 71 & 400 & 80 \\
\hline \multirow[t]{2}{*}{ ( $>15$ Yrars) } & $\mathrm{B} 2(50 \%)$ & 80 & 49 & 34 & 55 & 17 & 235 & 47 \\
\hline & $\mathrm{B} 3(0 \%)$ & 79 & 35 & 24 & 60 & 37 & 235 & 47 \\
\hline Total of A3 & & 247 & 195 & 94 & 209 & 125 & 870 & \\
\hline Total & & 394 & 585 & 296 & 734 & 220 & 2229 & \\
\hline
\end{tabular}

Descriptions:

I = Bukit Sentang; A = Group of Age

$\mathrm{II}=$ Padang Mandarsyah; $\mathrm{B}=$ Epiphyte

$\mathrm{III}=$ Ajamu

IV $=$ Sijambu-jambu

$\mathrm{V}=$ Aek Pancur

The analysis showed that the age difference does not affect the oil palm canopy number of individual insects. Epiphytes is very real existence affects the number of individual insects canopy, differences in study site is also real influence, but influence the interaction of different age groups and the presence of epiphytic no effect. DNMRT further test with confidence interval of $0.5 \%$ showed that the presence of epiphytic real $100 \%$ higher than the number of insects epiphytic $50 \%$ and $0 \%$ with an average increase of 81.0667. While the location of Padang Mandarsah and Sijambu-jambu has a number of real insects more to the value of the average increment of 65 and 81.556 comparison site Ajamu Gardens, Aek Pancur Gardens and the Bukit Sentang Gardens. 
Table 11. Effect of epiphytes and the age difference of the amount of oil palm canopy insect family in North Sumatra.

\begin{tabular}{|c|c|c|c|c|c|c|c|c|}
\hline \multirow{2}{*}{$\frac{\text { Age main plot }}{\operatorname{Umur}(\mathrm{A})}$} & \multirow{2}{*}{$\frac{\text { Subplot of }}{\text { Epiphytes (B) }}$} & \multicolumn{5}{|c|}{ Family number of insect } & \multirow[t]{2}{*}{ Total } & \multirow[t]{2}{*}{ Average } \\
\hline & & I & II & III & IV & $\mathrm{V}$ & & \\
\hline \multirow[t]{3}{*}{ A1 } & B1 & 11 & 22 & 4 & 26 & 21 & 84 & 16,8 \\
\hline & B2 & 6 & 20 & 7 & 10 & 12 & 55 & 11 \\
\hline & B3 & 5 & 24 & 7 & 16 & 12 & 64 & 12,8 \\
\hline Total of A1 & & 22 & 66 & 18 & 52 & 45 & 203 & \\
\hline \multirow[t]{3}{*}{ A2 } & B1 & 15 & 8 & 10 & 18 & 11 & 62 & 12,4 \\
\hline & B2 & 6 & 16 & 8 & 8 & 7 & 45 & 9 \\
\hline & B3 & 11 & 12 & 7 & 11 & 9 & 50 & 10 \\
\hline Total of A2 & & 32 & 36 & 25 & 37 & 27 & 157 & \\
\hline \multirow[t]{3}{*}{$\mathrm{A} 3$} & $\mathrm{~B} 1$ & 16 & 16 & 11 & 18 & 7 & 68 & 13,6 \\
\hline & B2 & 19 & 17 & 11 & 12 & 6 & 65 & 13 \\
\hline & B3 & 13 & 16 & 15 & 22 & 5 & 71 & 14,2 \\
\hline Total of A3 & & 48 & 49 & 37 & 52 & 18 & 204 & \\
\hline Total & & 102 & 151 & 80 & 141 & 90 & 564 & \\
\hline
\end{tabular}

Description:

$\mathrm{I}=$ Bukit Sentang; $\mathrm{A}=$ Group of Age Kelompok Umur

$\mathrm{II}=$ Padang Mandarsyah; $\mathrm{B}=$ Epiphytes

III = Ajamu

IV = Sijambu-jambu

$\mathrm{V}=$ Aek Pancur

The results of these analyzes showed that trees with epiphytes have a number of species and number of individuals were significantly higher than the tree without epiphytes. The insects can be grouped according to their role in the ecosystem, which is useful insects, insect pests, insects and insect neutral unknown role. Detailed data is the role of insects in oil palm plantations are shown in Table 12.

Table 12. Number of canopy insects caught in oil palm plantations in North Sumatra in accordance with its role in the ecosystem.

\begin{tabular}{lllll}
\hline \multirow{2}{*}{ Location } & \multicolumn{3}{l}{ Insect role } \\
\cline { 2 - 5 } & Useful & Pest & Netral & Unknown \\
\hline Bukit Sentang & 180 & 23 & 180 & 18 \\
Padang Mandarsyah & 306 & 53 & 366 & 31 \\
Ajamu & 155 & 47 & 189 & 33 \\
Sijambu-jambu & 227 & 145 & 112 & 23 \\
Aek Pancur & 453 & 150 & 343 & 56 \\
\hline
\end{tabular}

Overall insects fact that this estimate is the most useful insects and neuters. When viewed by age group and presence epifitnya palm turned out beneficial insects and insect remains neutral for more, both in epiphytes condition of $100 \%, 50 \%$ or $0 \%$. Nevertheless, there have also been found insect pests more than useful insects, which in Aek Pancur Gardens, Gardens Sijambu-pink at the age $>15$ years old and $50 \%$ epiphytes.

As useful organisms, insects on the role of natural enemies either as parasitoids and predators, insect pollinators and decomposers. While neuters often fall prey to predators, so a very large role in maintaining the balance of the ecosystem.
One insect predators that are found are spiders (Order Araneae). Insects found useful is that acts as a predator, for example of the order Araneae (spiders) and Dermaptera. Family Formicidae also many who acted as a predator for example Oecophyla smaragdina, Camponotus sp., Hypoponera sp., Pheidole sp., Tetramorium sp., Strumigenys sp., Technomyrmex sp., Odontomachus sp., And others. Other relatives who act as predators among others Reduviidae, Coccinelidae, Cantharidae and Anthicidae. There is also a role as a biocontrol like Aphytis sp., Nipponochalcidia sp., Parasitoid as Apantheles sp., Gavrana sp., Goryphus sp., Spathius sp., Orgilus sp., Phanerotoma sp.

Species Dermaptera, some Coleoptera, especially from the family Coccinellidae and some ant species of the genera Pachicondyla, Odontomachus (Ponerinae) and Crematogaster (Myrmicinae) are predators and can help to protect epiphytic herbivores. Spiders (Order Araneae) is a member of the arthropod phylum which has high adaptability to different types of environments. Spiders are predators for insects in the vicinity. Thus, the Spiders have an important role in the food chain. Spiders also have a role in agriculture, plantations, and housing is to protect from insects destroyer. Spiders are cosmopolitan animals that can live anywhere. Spiders can be found in terrestrial habitats, arboreal, and some aquatic. One habitat is oil palm plantations.

\section{Conclusion}

The results of this study suggest that it is very important to maintain the diversity of vascular epiphytes in an oil palm plantation in an effort that can be done to increase the 
diversity of insects canopy. Preservation of biodiversity in and around the oil palm plantations can help to ensure that the checks and balances that normally regulate invasive species and pest outbreaks in their natural habitat be kept functioning.

\section{Acknowledgement}

The authors are grateful to Hamonangan Tambunan, for his help with the authors.

\section{References}

[1] Altieri, M. A. and C. I. Nicholls. (1999). Biodiversity, Ecosystem Function, and Insect Pest Management in Agricultural System, in Biodiversity in Agroecosystems, Eds. W. W. Collins \& C. O. Qualset. Lwis Publ. New York. pp. 69-84.

[2] Ginting, K., E. S. Sutarta dan R. Y. Purba, 2004. Pengendalian Gulma Epifit Pada Kelapa Sawit. Warta PPKS, 12 (2-3): 23-27.

[3] Cruz-Ang et al. (2009). The contribution of epiphytes to the abundance and species richness of canopy insects in a Mexican coffee plantation. Journal of Tropical Ecology, 25, 453-463. doi: 10.1017/S0266467409990125.

[4] Brown, S., \& Lugo, A. E. (1990). Tropical secondary forests. Journal of Tropical Ecology, 6(01), $1 . \quad$ doi: $10.1017 / \mathrm{s} 0266467400003989$.

[5] Fitzherbert, E. B., M. J. Struebig, A. Morel, F. Danielsen, C. A. Bruhl, P. F. Donald dan B. Phalan. (2008). "How will oil palm expansion affect biodiversity?" Trends in Ecology and Evolution, 23, 538-45.

[6] Mackinnon, P. J., \& Alderton, M. R. (2000). An investigation of the degradation of the plant toxin, ricin, by sodium hypochlorite. Toxicon, 38(2), 287-291. doi: 10.1016/s00410101(99)00142-7.

[7] Corley, R. H. V., \& Tinker, P. B. (Eds.). (2003). The Oil Palm. doi: $10.1002 / 978047075097$.

[8] Danielsen, F., Beukema, H., Burgess, N., Parish, F., Brühl, C., Donald, P., Fitzherbert, E. (2009). Biofuel plantations on forested lands: Double jeopardy for biodiversity and climate. IOP Conference Series: Earth and Environmental Science, 6(24). doi: 10.1088/1755-1307/6/4/242014.

[9] Hanski, I., \& Gilpin, M. E. (1997). Preface. Metapopulation Biology, xv-xvi. doi: 10.1016/b978-012323445-2/50001-8.

[10] Li, Q., Moorhead, D. L., DeForest, J. L., Henderson, R., Chen, J., \& Jensen, R. (2009). Mixed litter decomposition in a managed Missouri Ozark forest ecosystem. Forest Ecology and Management, 257(2), 688-694. doi: 10.1016/j.foreco.2008.09.043.

[11] Hietz, P. 1999. Diversity and conservation of epiphytes in a changing environment. Pure Appl. Chem.70:2114. http://uipac.Org/symposia/proceedings/phuket97/hietz. (diakses: 26 Oktober 2013).

[12] Green, N. D. C., Brown, M. D., \& Coote, J. H. (2007). Failure of vascular autoregulation in the upper limb with increased +Gz acceleration. Eur J Appl Physiol, 100(6), 621-626. doi: 10.1007/s00421-007-0465-0.
[13] Essandoh, P. K., Armah, F. A., Odoi, J. O., Yawson, D. O. and Afrifa, E. K. A. 2011. Floristic Composition and Abundance of Weeds in an Oil Palm Plantation in Ghana.ARPN. Journal of Agriculture and Biological Science, 6(1).

[14] Zotz, G., \& Vollrath, B. (2003). The epiphyte vegetation of the palm Socratea exorrhiza - correlations with tree size, tree age and bryophyte cover. Journal of Tropical Ecology, 19(01). doi: $10.1017 / \mathrm{s} 0266467403003092$.

[15] Southwood, T. R. E. and Way. M. J. (19700. Ecological background to pest management. in Concepts of Pest Management, pp.7-13. R. L. Rabb \& F. E. Guthrie, eds. North Carolina State University, Raleigh. Van Driesche, R. G. \& T. S. Bellows Jr. 1996.Biological Control.Chapman and Hall. New York.

[16] Mattson, W. J. J. (1980). Herbivory in relation to plant nitrogen content. Annual Reviewof Ecology \& Systematics, 11, 119-161.

[17] Lawrence, G. H. M. 1951. Taxonomy of Vascular Plants. The Macmillan Company, New York.

[18] Sastrapradja, S., J. J. Afriastini, D. Darmedi dan Elizabeth. (1980). Jenis Paku Indonesia. Lembaga Biologi Nasional, Bogor.

[19] Piggott, A. G. (1984). Fern of Malaysia in colour. Tropical Press, ISBN 9677300296. Kualalumpur. Malaysia.

[20] Foster, A. S. and E. M. Gifford, Jr. (1967). Comparative Morphology of Vascular Plants. Second Indian Edition.Vaklis, Feffer and Simons Private Ltd. Bombay.

[21] Magurran, A. E. (1988). Ecological Diversity and Its Measurement. New Jersey: Princeton University Press.

[22] Mueller-Dombois, D. and Ellenberg, H. (1974) Aims and methods ofvegetation ecology.John Wiley \& Sons, New York, USA.Nation, J. L., 2002. Insect physiology and Biochemistry. CRC Press, Boca Raton.

[23] Michael, P. (1995). Metode ekologi untuk penyelidikan lading dan laboratorium. Jakarta: UI Press.

[24] Aththorick, T. A., E. S. Siregar dan S. Hartati. 2007. Kekayaan Jenis Makroepifit Di Hutan Telaga Taman Nasional Gunung Leuser (Tngl) KabupatenLangkat. Jurnal Biologi Sumatera, Vol. 2(1): 12-16.

[25] Danielsen, F. and M. Heegaard, 1995. Impact of logging and plantation development onspecies diversity: a case study from Sumatra. Management of tropical forests: towards an integrated perspective, Centre for Development and the Environment, Universityof Oslo.Norway.

[26] Fitzherbert, E. B., M. J. Struebig, A. Morel, F. Danielsen, C. A. Bruhl, P. F. Donald dan B. Phalan. (2008). "How will oil palm expansion affect biodiversity?" Trends in Ecology and Evolution, 23: 538-45.

[27] Benzing, D. H. (2004). Vascular Epiphytes. Forest Canopies, 175-211. doi:10.1016/b978-012457553-0/50014-9.

[28] Nieder, J., dan W. Barthlott. (2001). Epiphytes and their role in the tropical forest canopy. In J. Nieder and W. Barthlott (Eds.).Epiphytes and canopy fauna of the Otonga Rain Forest (Ecuador), vol. 2, pp. 23-86. Results of the Bonn-Quito epiphyte project funded by the Volkswagen Foundation, Bonn, Germany. 
[29] Yusuf, F. B., Tan, B. C, and Turner, I. M. (2003). Species Richness of Pteridophytes in Natural Versus Man-Made Lowland Forests in Malaysia and Singapore. Pteridology in The New Millenium. 283-298. Kluwer Academic Publisher.

[30] Ruiz-Cordova, J. P., Toledo-Hernández, V. H., \& FloresPalacios, A. (2014). The effect of substrate abundance in the vertical stratification of bromeliad epiphytes in a tropical dry forest (Mexico). Flora - Morphology, Distribution, Functional Ecology of Plants, 209(8), 375-384. doi: 10.1016/j.flora.2014.06.003.

[31] Johansson, D. (1974). Ecology of vascular epiphytes in West Africanrain forest. Acta Phytogeographica Suecica, 59: 1136

[32] Hietz, P. and U. Hietz-Seifert. (1995). Intra- and interspecific relations within an epiphyte community in a Mexican humid montane forest. Selbyana, 16, 135-140.

[33] Haro-Carrión, X., Lozada, T., Navarrete, H., de Koning, G. H. J. (2009). Conservation of the vascular epiphyte diversity in shade cacao plantations in the Chocó region in northwestern Ecuador. Biotropica, 41: 520-529.

[34] Nadkarni, N. M. (2002). Potential effect of climate change on canopy communities in a tropical cloud forest: An experimental approach. Oecologia, 131: 580-586.

[35] Barthlott, W., V. Schmit-Neuerburg, J. Nieder, dan S. Engwald. (2001). Diversity and abundance of vascular epiphytes; A comparison of secondary vegetation and primary montane rain forest in the Venezuelan Andes. Plant Ecology. 152: $145-156$.

[36] Krebs, C. J. (1985). Ecology. The Experimental Analisys of Distribution and Abundance. Third Edition.Harper \& Row Publisher. New York.

[37] Stuntz, S., C. Ziegler, U. Simon, and G. Zotz. (2002). Diversity and structure of the arthropod fauna within three canopy epiphyte species in central Panama. Journal of Tropical Ecology, 18, 161-176.
[38] Michael, P. 1995. Metode ekologi untuk penyelidikan lading dan laboratorium. Jakarta: UI Press.

[39] Pelawi, A. P. (2009). Indeks Keanekaragaman Jenis Serangga Pada Beberapa Ekosistem di Areal Perkebunan PT. Umbul Mas Wisesa Kabupaten Labuhanbatu. Skripsi. Universitas Sumatera Utara, Medan Indonesia.

[40] Haddad, N. M., M. C. Gregory, G. Kevin, H. John, T. David. (2011). Plant Diversity and The Stability of Foodwebs. Ecol. Lett, 14, 42-46.

[41] Mulder, C. P. H., J. Koricheva, K. Huss-Danell, P. Hoegberg, J.Joshi. (1999). Ecol. Lett. 2, 237-246.

[42] Gillison A and Liswanti N. (1999). Impact of oil palm plantations on biodiversity in Jambi, Central Sumatra, Indonesia. Bogor, Indonesia: Center for International Forestry Research.

[43] Brühl, C. A. and T. Eltz, (2009). Fuelling the crisis: Species loss of ground-dwelling forest ants in oil palm plantations in Sabah, Malaysia (Borneo)."Biodiversity \& Conservation.

[44] Oka, I. N., (1995). Pengelolaan Hama Terpadu dan Implementasinya di Indonesia. UGM-Press, Yogyakarta.

[45] Suin, N. M. (1997). Ekologi Hewan Tanah. Bumi Aksara. Bandung.

[46] Padmawathe, R., Qureshi, Q., \& Rawat, G. S. (2004). Effects of selective logging on vascular epiphyte diversity in a moist lowland forest of Eastern Himalaya, India. Biological Conservation, $119(1), \quad 81-92 . \quad$ doi: 10.1016/j.biocon.2003.10.024.

[47] Larrea, M. L., and Werner, F. A. 2010. Response of vascular epiphyte diversity to different land-use intensities in a neotropicalmontane wet forest. Forest Ecology and Management. 260(11): 1950-1955. doi: 10.1016/j.foreco.2010.08.029 